\title{
Optimization of Thermal Behavior and Energy Efficiency of a Residential House Using Energy Retrofitting in Different Climates
}

\author{
Apeksha Shandilya*, Martin Hauer, Wolfgang Streicher \\ Institute of Structural Engineering and Material Sciences, Unit for Energy Efficient Buildings, University of Innsbruck, Austria
}

Received March 23, 2020; Revised June 5, 2020; Accepted June 16, 2020

Copyright $\odot 2020$ by authors, all rights reserved. Authors agree that this article remains permanently open access under the terms of the Creative Commons Attribution License 4.0 International License

\begin{abstract}
The poor performance of buildings does not only play a major role in energy consumption but is also responsible for thermal discomfort inside the building. Prior to planning the building retrofitting, decision-makers need to evaluate different retrofitting strategies and their potential measures of energy savings on the current energy scenario. Therefore, this paper aims to integrate these factors and provide guidance on the most appropriate building retrofitting solution for reduced energy demand and better thermal comfort using as reference a typical Indian single-family house. This house is evaluated under five different climates of India. The work is focused on the comparative energy and thermal comfort analysis by considering the building as a stand-alone object. The building envelope of the example house model is improved for each climatic zone by retrofitting and compared with the reference condition to determine the potential energy savings and thermal comfort using TRNSYS18. This work provides a competitive analysis of more than 20 building retrofitting scenarios. The research provides a suggestion by using the "feasible envelope features" for design codes which propose feasible and optimized retrofitting strategy by maintaining thermal comfort and a baseline reference specifically formulated for thermal energy efficiency.
\end{abstract}

Keywords Energy Efficiency, Building Envelope, Passive Techniques, Thermal Comfort, Energy Retrofitting, TRNSYS18

\section{Introduction}

Buildings with better indoor air conditions and low energy consumptions are mandatory to assure living quality and to reduce carbon-dioxide $(\mathrm{CO} 2)$ emissions of the building sector. Subsequently, retrofitting of existing buildings in the developing countries focuses on structural or aesthetic measures and mainly on historical buildings. While retrofitting can be capable of reducing energy demand by $30-80 \%$ in residential buildings in India depending on various factors [1], reducing energy consumption is of equal importance concerning its financial impact [2].

Governments around the world have taken strong measures toward the retrofit of existing buildings in terms of improving energy performance [3]. The European energy performance of buildings directive demands a $20 \%$ energy savings target by 2020 [4] compared to the 1990 values. To achieve this objective, EU countries must set cost-optimal minimum energy performance requirements for new buildings, for the major renovation of existing buildings, and for the replacement or retrofit of building elements (heating and cooling systems, roofs, walls and so on) [5].

Climate change is one of the major challenges of our time. From shifting weather patterns that threaten food production, to rising sea levels that increase the risk of catastrophic flooding, the impacts of climate change are global in scope and unprecedented in scale [6].

India is the second most populous country in the world with $17.6 \%$ of the world's population and it is projected that by 2022 India will surpass China's population [7]. India's energy consumption is set to grow by $4.2 \%$ a year by 2035 , faster than that of all major economies in the world, according to BP Energy Outlook [8].In the IEO2017 Reference case, the delivered energy consumption for residential and commercial buildings in India is expected to increase by an average of $2.7 \%$ per year between 2015 and 2040, more than twice the global average increase [9]. Approximately $45 \%$ of the total energy used in India is spent towards maintaining the thermal comfort conditions only in the residential building 
sectors [10]. For India, EIA expects residential electricity consumption to increase nearly twice as fast as total residential sector energy use from 2015 to 2040. Electricity's share rises from $46 \%$ of the energy delivered to India's residences in 2015 to $68 \%$ in 2040 [9]. Global warming and climate change are the contemporary threats to ecosystem services and biodiversity that have a huge impact on the environment, livelihood of communities, and economics across the world [11]. The headline of the finding of the United Nations Intergovernmental Panel on Climate Change (IPCC) mentions, "warming of the climate system is unequivocal", and "most of the observed increase in global average temperatures since the mid-20th century is very likely due to the observed increase in anthropogenic greenhouse gas concentrations" [12]. The world's governments can successfully tackle climate change by harnessing the capacity of building sector to significantly reduce GHG emissions [13]. The global building performance network (GBPN) reported that if the existing Business-As-Usual (BAU) policy for buildings is followed, India could easily experience an increase in building energy consumption and greenhouse gas (GHG) emissions of around $700 \%$ by 2050 compared to 2005 levels [10].

Passive energy technologies have received great attentions due to their capabilities in achieving less energy consumption and maintaining good thermal comfort in buildings. It is forecasted that it is possible to reduce the GHG emissions from the buildings through the implementation of effective energy conservation measures such as adoption of cooling technologies or green building concepts maximizing the renewable energy efficient equipment [14].

Retrofitting is one of the most suitable and promising solutions to reduce the energy crises in India and very helpful tool to create and maintain thermal comfort in the buildings. However, in the survey, it was found that, in most of the retrofitting projects, energy efficient retrofit strategies were not applied due to lack of knowledge about the amount of investment required and efficiency of the potential energy saving strategies [2]. In most of the cases, the complexity of retrofitting and financing are the leading factors, which appear as a barrier to intervention and update [15]. Energy performance of the building depends on the correct selection of retrofitting depending on outdoor climate condition. Characteristics of the existing building (design and climate condition) must be understood to comprehend the thermal behavior of retrofitting [16].

Numerous studies and case studies have performed for analyzing the impact of building retrofitting on energy performance of the commercial buildings all around the world e.g. Ahmed et al. performed case study of a commercial building in Egypt to analyze behavior of retrofitting to achieve better energy efficiency in building [3]. Building orientation must be chosen according to weather or climatic implications of the area because they strongly affect the building energy demand [17]. In comparison to the building state of art, where glazing transmits most heat from the outside, envelope retrofitting through glazing upgrade is decreasing cooling load and total energy consumption (heating and cooling). Just the replacement of a standard single pane window to a triple glazed window with LoE film can reduce about $31 \%$ of the cooling energy demand in hot arid climate [18]. Similar work was performed by Mark Levine et. Al. for analyzing impact of retrofitting tool for improving energy efficiency of commercial buildings in China [19].

Farheen bano and M.A. Kamal examined the role of building envelope for energy efficiency in office buildings in India for composite climate [20]. In this study, the potential of energy savings was determined using different building envelope strategies for composite climate.

While as per the IEO 2016 report $28 \%$ of total building energy is used in the residential buildings in order to achieve thermal comfort in the buildings, so far none case studies for analyzing the potential of thermal energy saving in Indian residential building are available to give insight to the researchers or professionals.

The objective of this study is to investigate, understand and discuss the behavior of numerous retrofitting strategies for a single-family house, which was supposed to be located at five different climatic zones of India. The purpose of pursuing this analysis was to find and set conclusions about the behavior of identical retrofitting in different climates. Also, this study discusses the impact of retrofitting on the thermal comfort inside the building. As an overall, this study provides a conceptual framework to improve the process of retrofitting in residential buildings in India.

\section{Climatic Zones of India: An Overview}

India is home to an extraordinary variety of climatic regions, ranging from tropical in the south to temperate and alpine in the Himalayan north, where elevated regions receive sustained winter snowfall. The country's climate is strongly influenced by the Himalayas and the Thar Desert [21]. Climate change is the most important global environmental challenge facing world and has implications on energy resources, natural ecosystem, agriculture and health. M.R.Senapati et. al discussed the Impact of Climate change on Indian agriculture and its mitigation properties in their work [22].

The significant variations in the climatic conditions across the country demand for different requirements to achieve thermal comfort in the buildings [23]. According to the available data in the Indian Bureau of Energy Efficiency (BEE), the four major climatic factors which have the greatest impact on human comfort in the 
buildings are temperature, wind, humidity, and solar radiation [24]. Also, these climatic factors are mainly responsible for the required energy demand to compensate thermal losses through a building envelope. Figure 1 shows that about $45 \%$ of major Indian cities come under warm and humid climate zone. The annual average maximum and minimum temperature, humidity, and other weather description are illustrated in Figure 1. Values shown in Figure 1 are taken from the weather file generated using the software Meteonorm-version 7 [25]. In addition, the resulting heating degree-days (HDD) and cooling degree-days (CDD) were calculated using the same weather data. $18^{\circ} \mathrm{C}$ was used as base temperature for the calculation of heating and cooling degree days [26].
However, later in the simulation for the energy simulation, the cooling set-point temperature is set at $24^{\circ} \mathrm{C}$ and for heating set-point temperature at $20^{\circ} \mathrm{C}$. Figure 1 illustrates the summary of weather condition for five different climates of India. In the present study Srinagar (at latitude of $34.09^{\circ} \mathrm{N}$ and longitude of $74.80^{\circ} \mathrm{E}$ ) [26], New Delhi (at latitude of $28.64^{\circ} \mathrm{N}$ and longitude of $77.22^{\circ} \mathrm{E}$ ) [26], Jodhpur (at latitude of $26.27^{\circ} \mathrm{N}$ and longitude of $73.01^{\circ} \mathrm{E}$ ) [26], Bombay (at latitude of $13.54^{\circ} \mathrm{N}$ and longitude of $72.49^{\circ} \mathrm{E}$ ) [26] and Bangalore (at latitude of $12.58^{\circ} \mathrm{N}$ and longitude of $77.35^{\circ} \mathrm{E}$ ) [26] are the five cities, which are taken from different climates of the India for the analysis. Graphical representation of relative humidity \& average temperature in five climates of India is shown in Figure 2.

\begin{tabular}{|c|c|c|c|c|c|c|}
\hline $\begin{array}{l}\text { Climate } \\
\text { Zone }\end{array}$ & Cities & $\begin{array}{l}\text { Yearly average } \\
\text { temperature } \\
\text { range (in }{ }^{\circ} \mathrm{C} \text { ) }\end{array}$ & $\begin{array}{l}\text { Relative } \\
\text { humidity } \\
\text { (in \%) }\end{array}$ & $\begin{array}{l}\text { Cold } \\
\text { Degree } \\
\text { Days }\end{array}$ & $\begin{array}{l}\text { Heating } \\
\text { Degree } \\
\text { Days }\end{array}$ & Description \\
\hline Cold & $\begin{array}{l}\text { Jamm- kashmir, } \\
\text { Laddakh, Sikkim, } \\
\text { Srinagar, Himachal } \\
\text { Pradesh }\end{array}$ & $4-26$ & $64-77$ & 523 & 2197 & $\begin{array}{l}\text { Low temperature during winter } \\
\text { Moderate temperature during summer } \\
\text { High solar radiation during sunny/cold days } \\
\text { Low humidity in cold/sunny days } \\
\text { High humidity in cold/cloudy days }\end{array}$ \\
\hline Composite & $\begin{array}{l}\text { New-Delhi, Punjab, } \\
\text { Haryana, Uttar- } \\
\text { Pradesh, Bihar, } \\
\text { Jharkhsnd }\end{array}$ & $15-36$ & $39-75$ & 2708 & 329 & $\begin{array}{l}\text { High temperature during summer } \\
\text { Low temperature during night } \\
\text { Low humidity in summer } \\
\text { High humidity in winter } \\
\text { High solar radiation except monsoon period }\end{array}$ \\
\hline Hot \& Dry & $\begin{array}{l}\text { Madhya-Pradesh, } \\
\text { Jaipur/Rajasthan, } \\
\text { Central } \\
\text { Maharashtra, } \\
\text { Ahemdabad etc. }\end{array}$ & $17-39$ & $25-68$ & 3330 & 81 & $\begin{array}{l}\text { Hot dry weather in the summer and cold in winter } \\
\text { Very little rain fall } \\
\text { Very low humidity } \\
\text { High temerature difference between day and night } \\
\text { High solar raditation } \\
\text { Clear sky most of the year } \\
\text { Hot winds and frequent dust stoms }\end{array}$ \\
\hline $\begin{array}{l}\text { Warm } \\
\text { and } \\
\text { Humid }\end{array}$ & $\begin{array}{l}\text { Mumbai, Chennai, } \\
\text { Kerala, Coastal part } \\
\text { of Orissa }\end{array}$ & $20-36$ & $57-80$ & 3325 & 0 & $\begin{array}{l}\text { Moderate temperature } \\
\text { Moderate humidity during day } \\
\text { High humidity during night } \\
\text { Diffused solar radiation in cloudy days } \\
\text { Intense direct solar radiation in clear (clodless) } \\
\text { days }\end{array}$ \\
\hline Temperate & Bangalore, Goa etc. & $17-32$ & $48-79$ & 1958 & 0 & $\begin{array}{l}\text { Moderate temperature } \\
\text { Moderate humidity } \\
\text { Solar radiation same throughout year (clear sky) }\end{array}$ \\
\hline
\end{tabular}

Figure 1. Summary of weather condition for five different climates of India, Source: Author, based on weather data generated using meteonorm version 7. Source: climate zones of India ECBC 2007
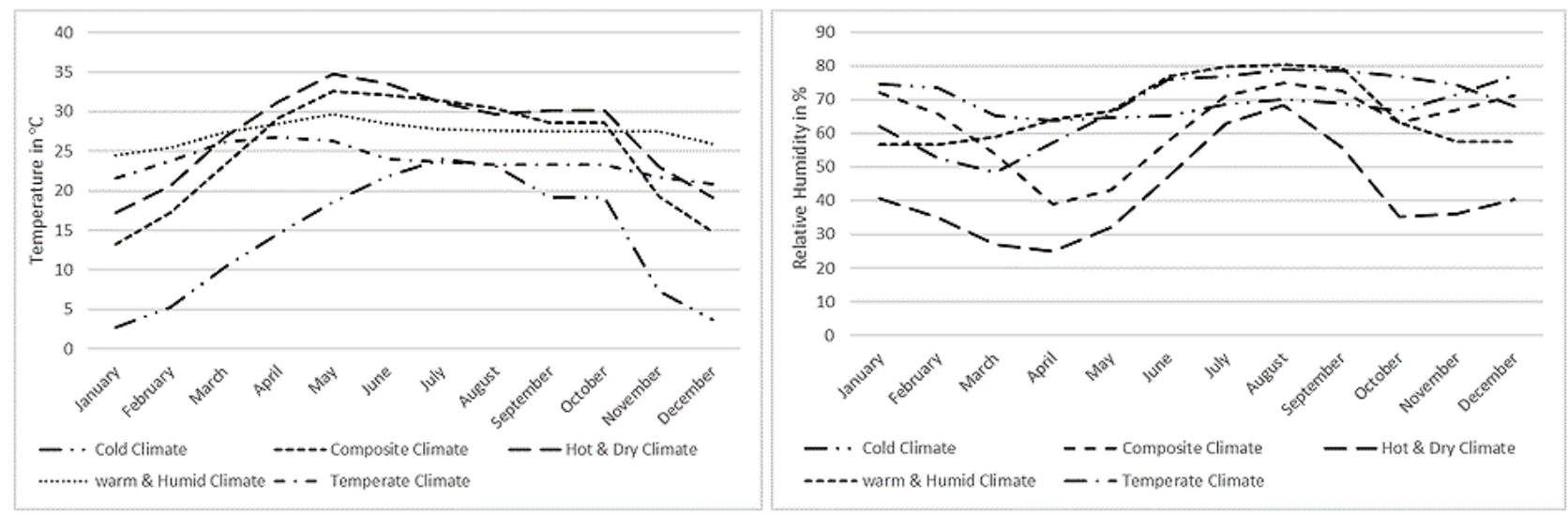

Figure 2. Average temperature and Relative humidity in Indian climates, based on weather data generated using Meteonorm-version 7

This variety of climates also cover many climates of neighboring Asian countries. 


\section{Methodology}

To achieve the mentioned objectives of the study the following set of procedures were used:

At first, the simulation of a reference building model was performed for the actual conditions to calculate the thermal load and energy performance of the building. Different retrofitting combinations are analyzed in order to achieve the lowest cooling and heating demand in the investigated building at five different locations. Also, the thermal comfort index, predictive mean vote (PMV) were calculated, analyzed and discussed for the reference and the improved scenarios.

The methodology adopted for this study is expressed in Figure 3.

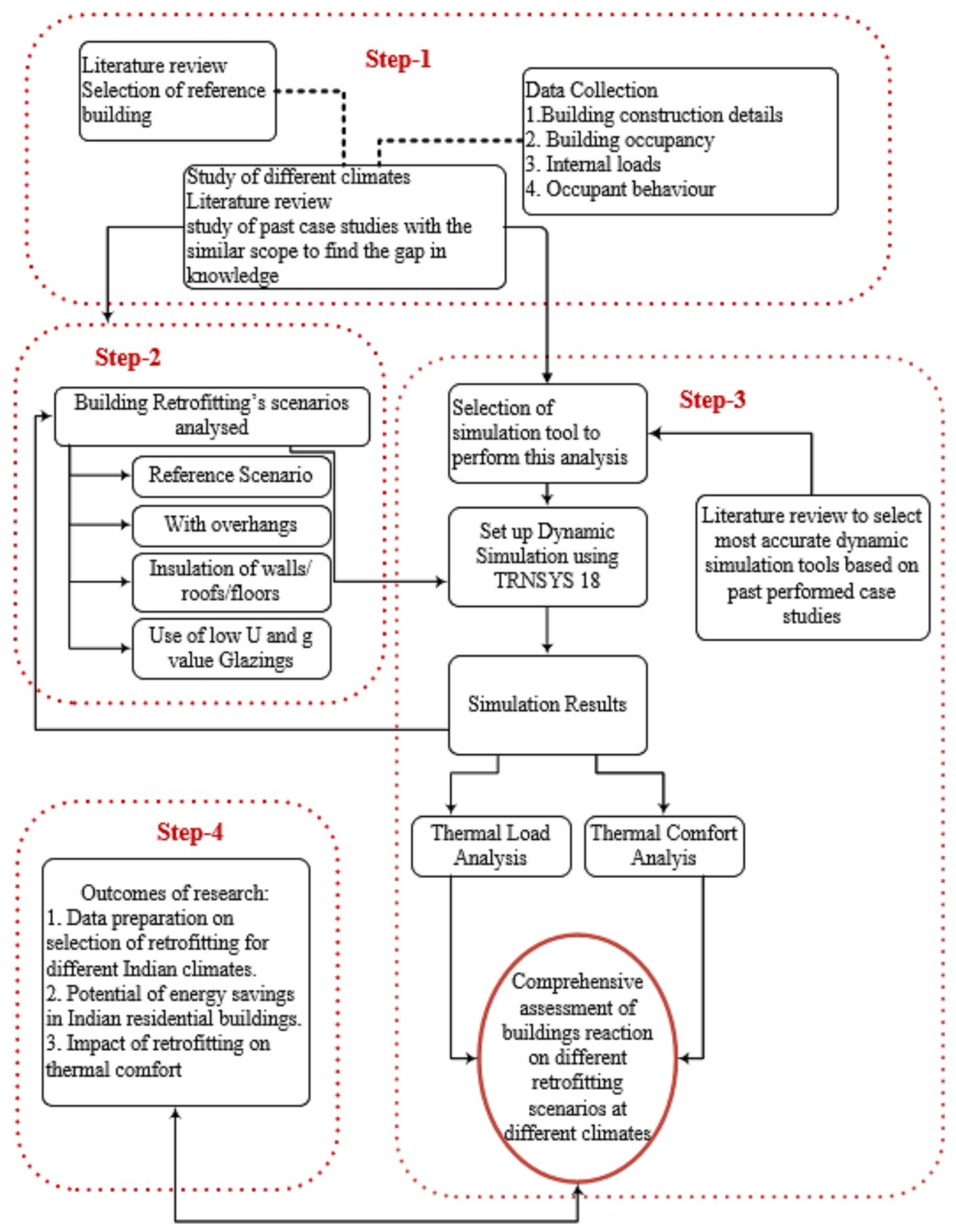

Figure 3. Research methodology 


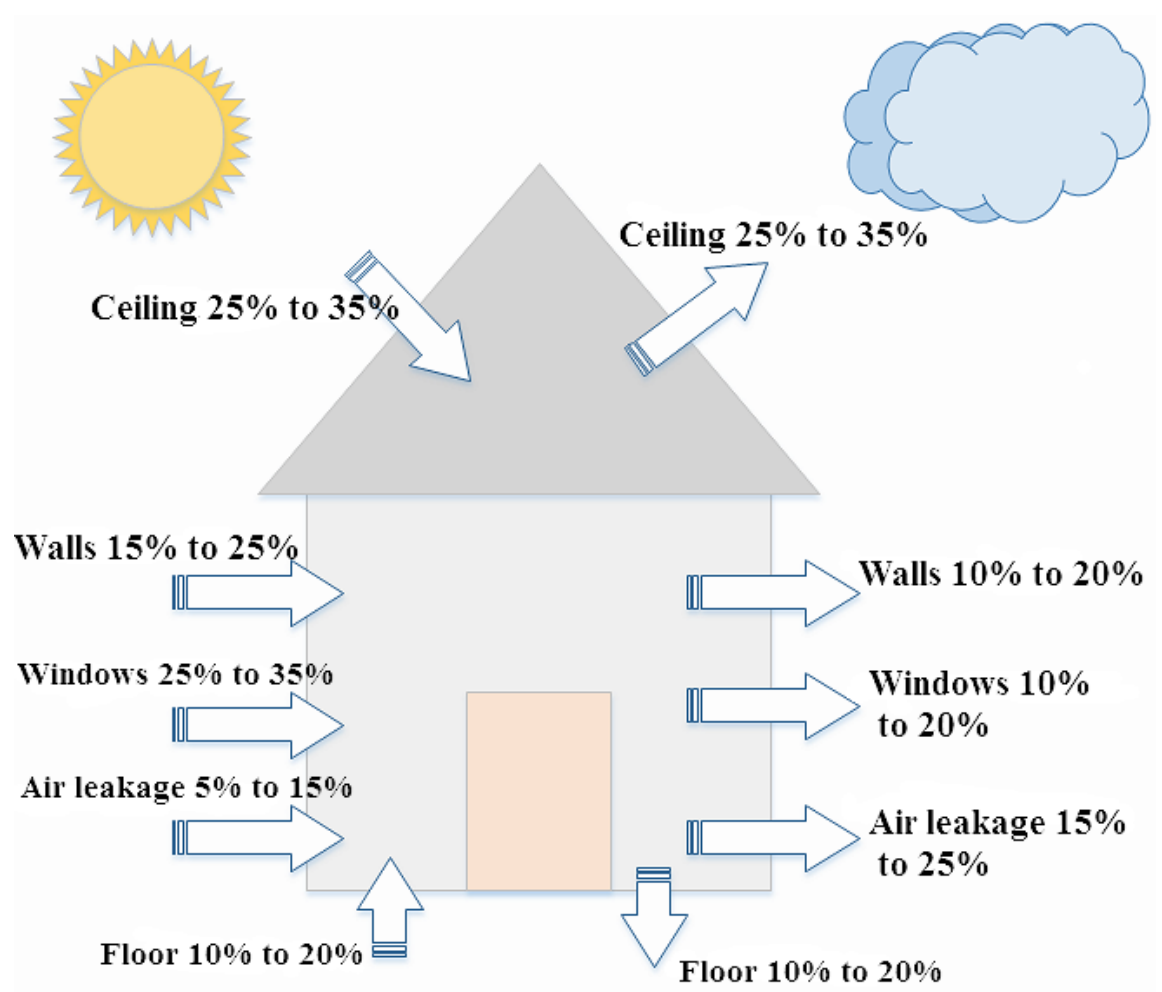

Figure 4. Typical heat loss and heat gain through a poorly insulated building in colder and hotter days for Indian climates [1]

\subsection{Thermal Load Calculation}

TRNSYS 18 is used to predict building thermal load and thermal response. Building thermal load is the quantity of heat that must be removed (cooling load) and added (heating load) to maintain a constant comfortable room temperature, heat transfer into and out of the example building model is analyzed for different combinations. Figure 4 shows the main heat fluxes that occur in a poor house (The values are based on simulated data).

\subsection{Retrofitting Strategies for This Study}

\subsubsection{Insulated walls, floors and roof}

There are a number of insulation materials, which are available on the market to improve the thermal insulation of a building. The amount of energy saving per year using insulation material depends on factors like thermal conductivity of the insulation material, thickness of the insulation material and thermal capacitance of the insulation material [1].

For the present work, it is considered Expanded Polystyrene (EPS) having thermal conductivity $(\lambda) 0.03$ $\mathrm{W} /(\mathrm{m}-\mathrm{K})$ as an insulation material for improving the thermal envelope, the thickness of insulation layer is 50 $\mathrm{mm}$ for walls and floor and $100 \mathrm{~mm}$ for the roof. This value is chosen based on previous studies [1].

\subsubsection{Improved windows}

Energy efficient windows are an important consideration for both new and existing homes. The total thermal transmittance (frame and glazing) varies with the number of glazing, type of coatings and type of filled gases between the glazing. Heat gain and heat loss through windows are responsible for $25 \%-30 \%$ of residential heating and cooling energy use [1]. Replacing the high U-value windows by low U-value windows helps in energy saving as well as in achieving better thermal comfort inside the building. The g-value of a glass describes the solar heat gain through a glazing towards the interior via transmission and secondary heat flux. Higher g-value glass can be favorable for the cold climate where solar heat gain creates the thermal comfort inside the building. In the same time, it is not encouraging to use high g-values in the climates where cooling of the building is the bigger aim [1]. Sometimes replacing the low efficiency windows with high efficiency windows is expensive [1].

In this study, initially, the building is equipped with single pane glass ( $4 \mathrm{~mm}$ thick) windows which is typically for standard Indian houses. The glazing area represents $18 \%$ of the total wall area. The glazing area of the south, west, and east wall has $16.6 \%$ of wall area while the glazing in the north wall is set to $22.2 \%$ of the wall area. The U-value and g-value of the window materials are 5.75 $\mathrm{W} / \mathrm{m}^{2} \mathrm{~K}$ and 0.902 respectively. For analyzing the behavior of efficient windows at different climate, we exchanged the single pane windows with triple pane windows filled with Argon/Air (90\% argon; 10\% air) gas mixture. The corresponding U-value and g-value of triple pane windows are 0.76 and 0.5 respectively. This value 
represents the mean value of the center of glazing and wooden frame of the windows. The simulations are performed and compared, the effect of high efficiency windows on heating and cooling energy demand over the low efficient windows, while the building is situated at five different climates, is shown and analyzed.

\subsection{Analysis of Thermal Comfort}

Thermal comfort has been defined as the condition of mind, which illustrates satisfaction with the thermal environment, and thermal sensation is related to thermal balance between the human body and its ambient thermal condition [27]. Depending on the heat transfer, via heat gain or loss, the thermoregulation system in a human brain regulates skin temperature to maintain a constant core body temperature of $36.5^{\circ} \mathrm{C}$ [27].

It has been proved from various experiments that the temperature sensation and the perception of thermal comfort are related to the thermal state of the human body, as detected by the thermos-receptors, that they depend on the skin and core body temperature respectively and their variation over time [28].

The concept of Predicted Mean Vote (PMV) index is introduced and discussed with respect to people's behavioral adaptation calculated from an equation of thermal balance for the human body, involving the terms of internal generation and heat exchanges with the surrounding environment [29]. The value of the thermal comfort index PMV, which is an estimate of the expected average vote of a panel of evaluators for a given thermal environment, is calculated by the method developed by Fanger (1972) [30] and adapted in ISO 7730:2005 (Ergonomics of the thermal environment -- Analytical determination and interpretation of thermal comfort using calculation of the PMV and PPD indices and local thermal comfort criteria).

Predictive mean vote (PMV index) expressed through the vote of comfort on a scale ranging from -3 (very cold) to +3 (very hot). The other index proposed in ISO Standard 7730 is PPD (Predicted Percentage of Dissatisfied) that quantifies the expected percentage of dissatisfied people in a given thermal environment. Dynamic simulation of the building was performed using TRNSYS (Transient system simulation tool) [31] to analyze the thermal comfort by calculating PMV and PPD. Relative humidity, air temperature, mean radiant temperature, relative air velocity, clothing factor and the activity level has the combined influence on the PMV and PPD values.

Thermal neutrality is maintained when the heat generated by human metabolism is allowed to dissipate, thus maintaining thermal equilibrium with the surroundings and keeping the normal body temperature.

\section{Description of the Reference Building}

\subsection{Construction of the Building}

The reference building is a one-floor single-family house, which was constructed in the year 1980, in the part of central India. Figure 5 shows the actual building and 3D geometry model drawn in Trimble Sketch-up, which is later on imported as Multi-Zone building energy model (Type56) in the TRNSYS Simulation Studio.

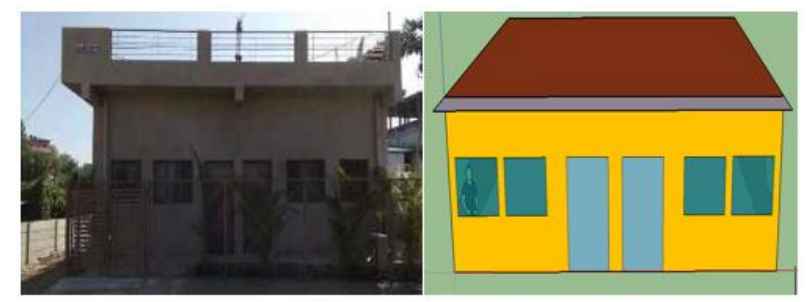

Figure 5. Actual Building (left) and 3D model prepared in sketch-up for thermal simulation (right).

In this study, we assumed that the same building is located at five different locations of India. The construction has concrete and brick structure. The floor and the roof have concrete structure; marble used as a surface of the floor to provide good finish, look, and strength to the floor. The walls are built of cement, sand, and brick with no thermal insulation. The building has standard single glazing windows, and window frames are made of wood. The doors are also made of wood. The house has south entrance. The important technical data with transmittance values of the studied example building are provided in Table 1: Technical data of studied example single family house.

Table 1. Technical data of studied example single family house

\begin{tabular}{|c|c|c|c|c|}
\hline Building Volume & $324\left(\mathrm{~m}^{3}\right)$ & Glazing area & $18 \%$ of wall area & \\
\hline Floor Area $\left(\mathrm{m}^{2}\right)$ & $108(12 \times 9)$ & & Floor Height $(\mathrm{m})$ & 3 \\
\hline \multirow{2}{*}{ Building Envelope } & \multicolumn{2}{|c|}{ Reference case (without insulation) } & \multicolumn{2}{|c|}{ Optimized case (with insulation) } \\
\hline & $\mathrm{U}$-value $\left(\mathrm{W} / \mathrm{m}^{2} \mathrm{~K}\right)$ & Thickness (mm) & $\mathrm{U}$-value $\left(\mathrm{W} / \mathrm{m}^{2} \mathrm{~K}\right)$ & Thickness (mm) \\
\hline External walls & 2.15 & 225 & 0.46 & 275 \\
\hline Floor & 1.34 & 150 & 0.26 & 250 \\
\hline \multirow[t]{2}{*}{ Roof } & 1.12 & 250 & 0.23 & 350 \\
\hline & \multicolumn{2}{|c|}{ Reference case (Single-pane window) } & \multicolumn{2}{|c|}{ Improved case (3-pane windows) } \\
\hline \multirow[t]{2}{*}{ Glazing } & U-value $\left(\mathrm{W} / \mathrm{m}^{2} \mathrm{~K}\right)$ & g-value & U-value $\left(\mathrm{W} / \mathrm{m}^{2} \mathrm{~K}\right)$ & g-value \\
\hline & 5.75 & 0.902 & 0.76 & 0.5 \\
\hline
\end{tabular}


The thermal mass of the internal walls of the house was calculated externally using equation (4.1), which amounts to $18800 \mathrm{~kJ} / \mathrm{K}$ and used this quantity together with internal thermal mass of air which is $388.2 \mathrm{~kJ} / \mathrm{K}$. Therefore, for this study, the total capacitance is 19200 $\mathrm{kJ} / \mathrm{K}$.

Where:

$C=$ thermal mass (capacitance) of internal wall $(\mathrm{J} / \mathrm{K})$

$m=$ mass of wall layer $(\mathrm{kg})$

$C_{p}=$ specific heat of the wall layer material $(\mathrm{J} / \mathrm{kgK})$

$\rho=$ density of wall layer material $\left(\mathrm{kg} / \mathrm{m}^{3}\right)$

$V=$ volume of wall layer $\left(\mathrm{m}^{3}\right)$

Occupancy, schedule, and internal gains

It is assumed that a couple with their two kids live in this house. In this study, it is assumed that their duration of staying at home is a total of 15 hours (from 17:00 08:00) on weekdays and 24 hours on weekends. The clothing factor was specified as 0.5 , metabolic rate was 2 $\left(\mathrm{W} / \mathrm{m}^{2}\right)$ and relative air velocity $0.3 \mathrm{~m} / \mathrm{s}$ under comfort tab.

Moreover, due to this, the light and electrical equipment was considered in this work. The value of internal gains for per person was taken as $125 \mathrm{~W}$ as defined in standard EN13779 [32], activity level III, sedentary activity, air temperature of $24{ }^{\circ} \mathrm{C}$. As per this standard, the heat dissipation from the human body was $37.5 \mathrm{~W}$ (in form of convective power) and $37.5 \mathrm{~W}$ (in the form of radiative power). Gains from lights were considered $6 \mathrm{~W} / \mathrm{m}^{2}$ for this study while gains due to electrical equipment were considered $8 \mathrm{~W} / \mathrm{m}^{2}$, as defined in library SIA 2024 for area related equipment heat gain with the convective power $6.23 \mathrm{~W}$ and radiative power 1.6 W [33].

Infiltration and ventilation in the building

One of the challenging points in this study is the appropriate selection of infiltration. Before considering this value, we searched the literature thoroughly and based on previous studies the value of $1.1 \mathrm{ACH}$ (air changes per hour) was chosen as initial infiltration for this building as the building has loose structure, has some cracks in the walls, construction is more than 20 years old, and windows and doors are not air-tight [34]. In the optimized case, this value was assumed 0.45 $\mathrm{ACH}$. Both people and building-related sources of pollution are taken into account in newer standards for the required ventilation rates in buildings, which included ASHRAE 62.1 [1] [2] and EN15251 [32]. In this study, fresh air ventilation rates for acceptable indoor air quality in buildings were taken from ASHRAE standard 62 (2004) [34]. In this scenario, the required ventilation rate as per the standard was 0.4 $\mathrm{ACH}$.

Shading Device Control on Windows

In this work, a thorough analysis for defining the impact of shading devices on the energy demand of the building was performed.

Shading control is defined for summer and winter seasons as well as for south, west, north and east façade separately.

The shading control is designed to operate based on two conditions- winter and summer. For the winter season shading is suggested to be retracted (not active) so that solar radiation can create some heat gain during the daytime through windows to reduce the heating energy demand of the building. While, shading should be operated in summer days based on solar radiation to minimize the heat gain through windows. The shading is operated only from April to October depending on the received solar radiation on window surface. The shade is closed if the solar radiation is more than $140 \mathrm{~W} / \mathrm{m}^{2}$ on the window and open if the solar radiation on the window is less than $120 \mathrm{~W} / \mathrm{m}^{2}$.

\section{Results and Discussion}

\subsection{Retrofit Combinations}

The hourly weather data files used in the simulation are weather data in. $\mathrm{tm}^{2}$ format, created using meteonorm software version 7 [25]. For the calculation of HDD and $\mathrm{CDD}$, the base temperature considered is $18^{\circ} \mathrm{C}$ (refer figure 1) but, for the simulation in TRNSYS, the indoor temperature set point for cooling was $24{ }^{\circ} \mathrm{C}$ and for heating $20^{\circ} \mathrm{C}$ using the ideal heating and cooling option. No specific control is defined for indoor relative humidity in any of the systems in this study.

The shading control was primarily controlled based on radiation on the façade. 
Table 2. Description of retrofitting combinations used in this study

\begin{tabular}{|c|c|c|c|c|c|c|c|c|c|}
\hline \multirow[b]{2}{*}{ Case } & \multirow{2}{*}{$\begin{array}{l}\text { Description of } \\
\text { retrofitting scenarios }\end{array}$} & \multicolumn{3}{|c|}{ Insulation } & \multicolumn{2}{|c|}{ Windows } & \multirow{2}{*}{$\begin{array}{l}\text { Shading } \\
\text { control }\end{array}$} & \multirow{2}{*}{$\begin{array}{l}\text { Infiltration } \\
\text { (in ACH) }\end{array}$} & \multirow{2}{*}{$\begin{array}{l}\text { Over- } \\
\text { hangs }\end{array}$} \\
\hline & & walls & floor & roof & $\begin{array}{l}\text { U-Value } \\
\mathrm{W} /\left(\mathrm{m}^{2} \mathrm{~K}\right)\end{array}$ & $\mathrm{g}$-Value & & & \\
\hline $\mathbf{A}$ & Reference Scenario & No & No & No & 5.75 & 0.92 & No & 1.1 & No \\
\hline B & Building with overhangs & No & No & No & 5.75 & 0.92 & No & 1.1 & Yes \\
\hline $\mathbf{C}$ & Roof insulation & No & Yes & No & 5.75 & 0.92 & No & 1.1 & No \\
\hline D & $\begin{array}{l}\text { Single pane windows+ } \\
\text { shading control }\end{array}$ & No & No & No & 5.75 & 0.92 & Yes, Schedule & 1.1 & No \\
\hline $\mathbf{E}$ & $\begin{array}{l}\text { Roof insulation }+ \text { three } \\
\text { pane windows }\end{array}$ & No & Yes & No & 0.76 & 0.5 & No & 1.1 & No \\
\hline $\mathbf{F}$ & $\begin{array}{l}\text { Roof insulation }+ \text { three } \\
\text { pane windows }+ \text { shading }\end{array}$ & No & Yes & No & 0.76 & 0.5 & $\begin{array}{c}\text { Yes, } \\
\text { Schedule. }\end{array}$ & 1.1 & No \\
\hline G & $\begin{array}{l}\text { Three pane windows + } \\
\text { thermal envelope } \\
\text { insulation }\end{array}$ & Yes & Yes & Yes & 0.76 & 0.5 & No & 0.45 & No \\
\hline $\mathbf{H}$ & $\begin{array}{l}\text { Three pane windows + } \\
\text { thermal insulation }+ \\
\text { shading control }\end{array}$ & Yes & Yes & Yes & 0.76 & 0.5 & Yes, Schedule & 0.45 & No \\
\hline $\mathbf{I}$ & Basic infiltration & No & No & No & 5.75 & 0.92 & No & 1.1 & No \\
\hline $\mathbf{J}$ & $\begin{array}{l}\text { Reduced infiltration } \\
\text { with basic construction }\end{array}$ & No & No & No & 5.75 & 0.92 & No & 0.45 & No \\
\hline $\mathbf{K}$ & $\begin{array}{l}\text { Reduced infiltration } \\
\text { with insulated building } \\
\text { envelope+ three pane } \\
\text { windows }\end{array}$ & Yes & Yes & Yes & 0.76 & 0.5 & No & 0.45 & No \\
\hline $\mathbf{L}$ & $\begin{array}{l}\text { Basic construction }+ \\
\text { overhangs }\end{array}$ & No & No & No & 5.75 & 0.92 & No & 1.1 & Yes \\
\hline $\mathbf{M}$ & $\begin{array}{l}\text { Basic construction + } \\
\text { overhangs + shading } \\
\text { control }\end{array}$ & No & No & No & 5.75 & 0.92 & Yes, Schedule & 1.1 & Yes \\
\hline $\mathbf{N}$ & Actual scenario & Yes & Yes & Yes & 5.75 & 0.92 & No & 1.1 & Yes \\
\hline $\mathbf{O}$ & Building with overhangs & Yes & Yes & Yes & 5.75 & 0.92 & Yes, Schedule & 1.1 & Yes \\
\hline $\mathbf{P}$ & Roof insulation & Yes & Yes & Yes & 0.76 & 0.5 & No & 0.45 & Yes \\
\hline $\mathbf{Q}$ & $\begin{array}{l}\text { Single pane windowst } \\
\text { shading control }\end{array}$ & Yes & Yes & Yes & 0.76 & 0.5 & Yes, Schedule & 0.45 & Yes \\
\hline
\end{tabular}

\subsection{Results Concerning Energy Demand}

In the simulation the behavior of different combinations of retrofitting for the following scenarios on heating and cooling demand of the building was analyzed. All the retrofitting combinations are listed in Table 2: Description of retrofitting combinations is used in this study. The construction layer improvement in Figure 6 \& Figure 7, the effect of infiltration changes in Figure 8, and the effect of overhangs (Figure $9 \&$ Figure 10).

The dynamic simulation of the building is performed for all the retrofitting combinations that are mentioned in Table 2. In this study the modification in the building model is done in a way to understand the behavior of each of the retrofitting combination in the different climates. Therefore, the simulation of the building is performed after each modification. The potential of energy savings are shown for the different retrofitting actions in Figure 6 \& Figure 7. The results show that the roof insulation (Case C) has a potential of more than $15 \%$ of total energy savings (mainly for cooing) depending on the location (climate condition) of the building.

Substituting high U-value windows with the low $\mathrm{U}$-value windows is a good energy solution for the cold climate and composite climate (Case E, G and H: Figure 6). Windows are the main source of heat gain in the building due to solar radiation. Shading can control the amount of solar radiation coming through glazing. Therefore, shading control turned out to be an important solution especially for warm \& humid and temperate climate with more than $50 \%$ energy saving potential for the cooling energy demand (Figure 9: Case D, F \& H). Thermal envelope insulation was analyzed for five mentioned climates with the combination of other retrofitting strategies like airtight construction (low infiltration), shading control, low U-value windows etc. It turned out that the thermal envelope insulation of building is very important for the cold climate conditions. Insulated thermal envelopes can reduce more than $70 \%$ of heating energy demand of the building, which is located at cold climate (for absolute values refer to Figure 6: Case G \& $\mathrm{H})$. 


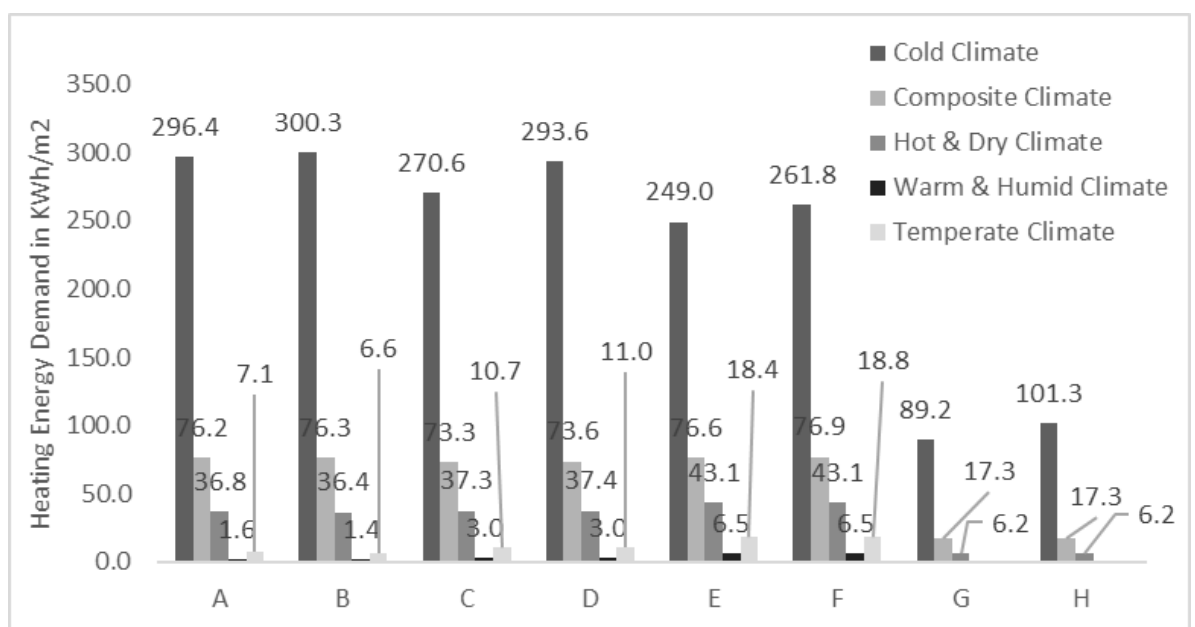

Figure 6. Impact of various retrofitting combination on heating demand. Here, A-H are the retrofitting combinations for details refer to Table 2.

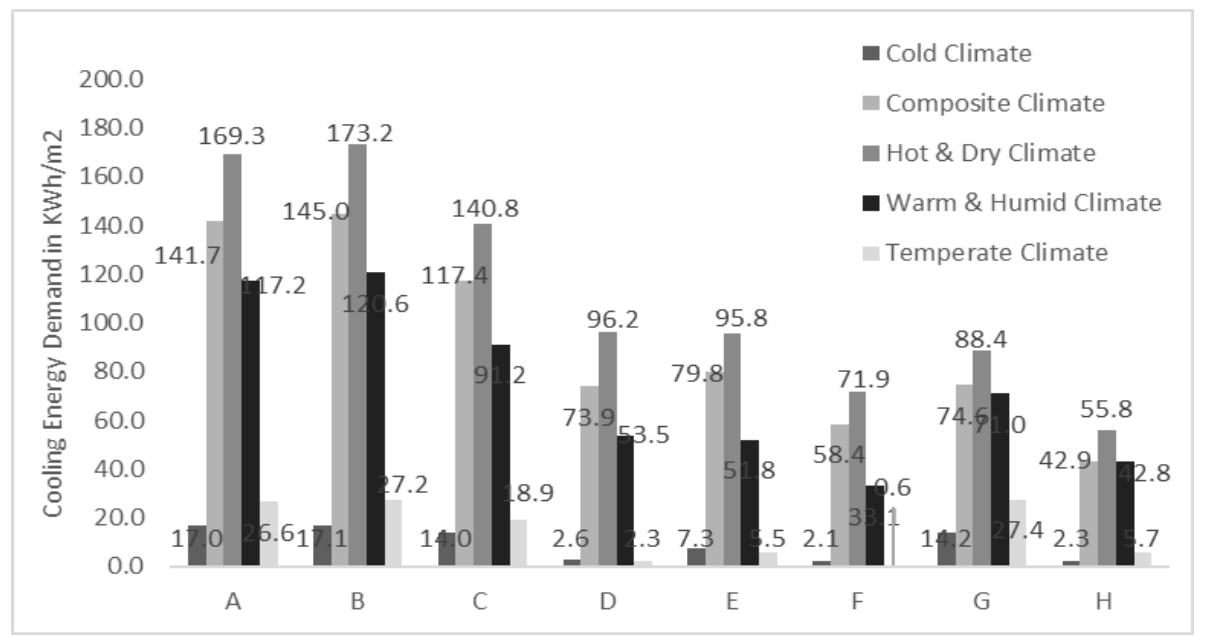

Figure 7. Impact of various retrofitting combination on cooling demand. Here, A-H are the retrofitting combinations for details refer to Table 2.

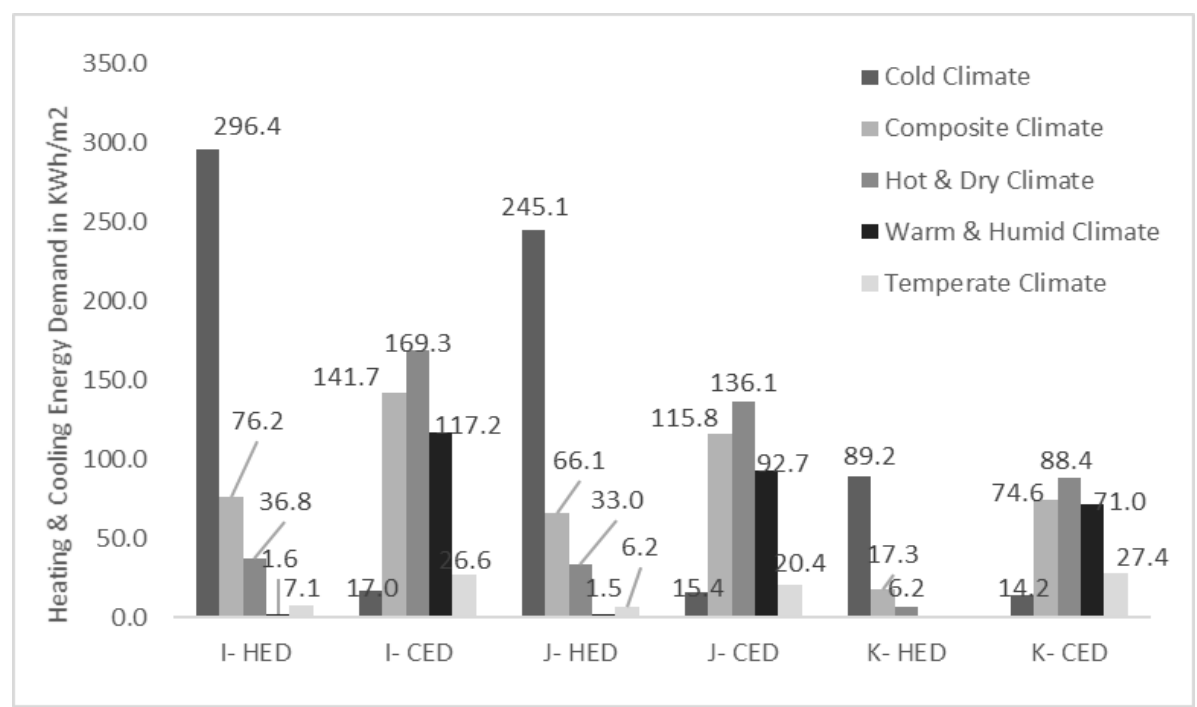

Figure 8. Effect of infiltration on heating and cooling energy demand of the building. Here, HED -Heating Energy Demand and, CED -Cooling Energy Demand and, I, J and K are retrofitting combinations, for details refer to Table 2.

The investigated building has a southern entrance and the south wall of the building is equipped with $1.5 \mathrm{~m}$ wide overhang. To analyze the effect of overhangs in the other three directions, we modeled the building that provided the same wider overhangs in all four directions. The dynamic simulation is performed for numerous retrofitting combinations for finding the potential of energy savings while the building is modelled to have overhangs on all 
external walls. The outcomes are shown in Figure $9 \&$ Figure 10. Overhangs have a large potential of decreasing cooling energy demand for hot climates but also it is responsible to increase the heating demand of building especially in winter time but as cooling load is not very critical for hot climates this value can be neglected. Except for cold and composite climate, overhangs are favorable. It is found that overhangs together with the radiation based shading control have the potential of $18 \%$, $28 \%$ and $64 \%$ of cooling energy savings in hot \& dry, warm \& humid and temperate climate, respectively.

The best retrofitting solutions in terms of energy savings and the potential of energy savings for the different climates are mentioned in Table 3: Initial and improved annual heating and cooling energy demand (in $\mathrm{kWh} / \mathrm{m}^{2}$ ) for five climates of India.

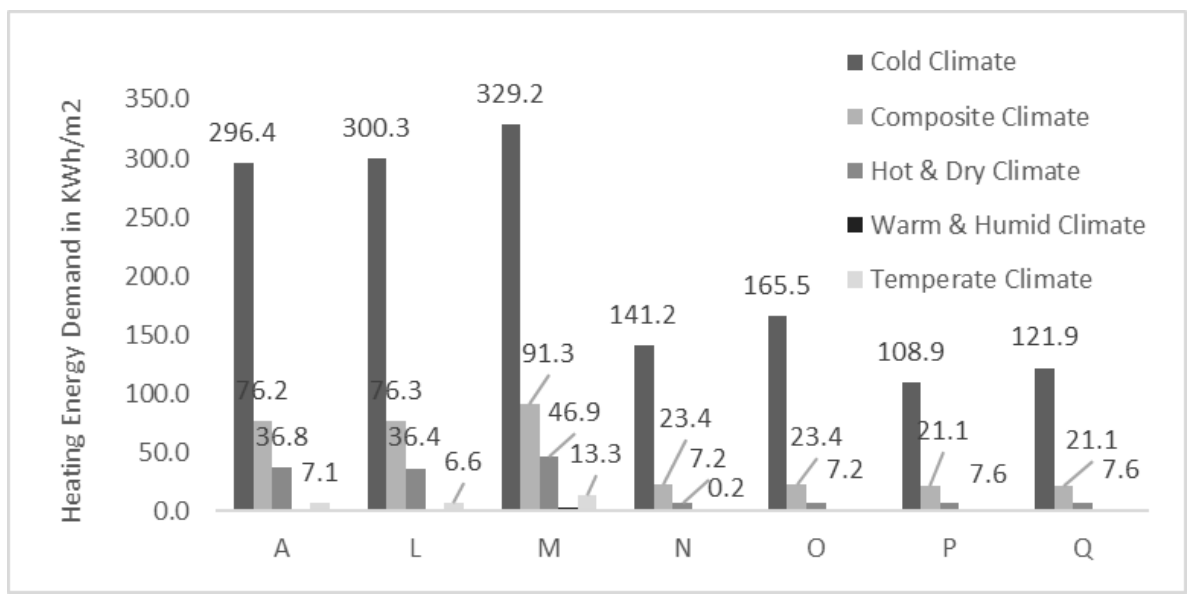

Figure 9. Effect of overhangs on heating energy demand in building, here, A. L-Q are the retrofitting combinations (refer Table 2)

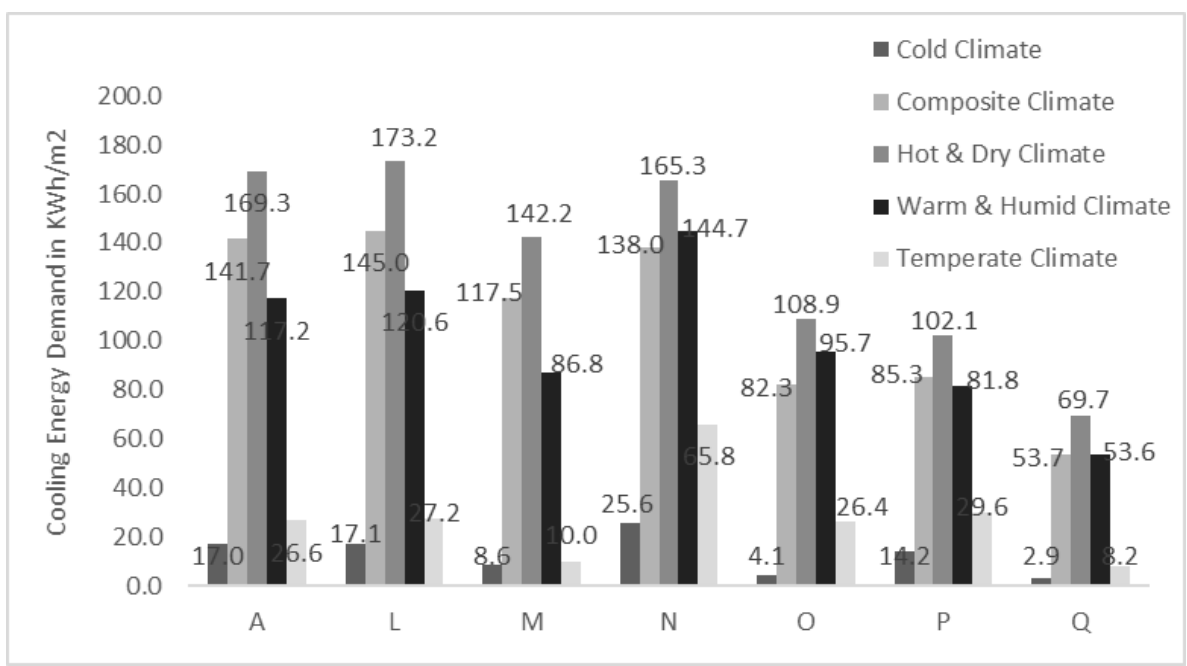

Figure 10. Effect of overhangs on cooling energy demand in building, here, A. L-Q are the retrofitting combinations (refer Table 2)

Table 3. Initial and improved annual heating and cooling energy demand (in $\mathrm{kWh} / \mathrm{m}^{2}$ ) for five climates of India

\begin{tabular}{|c|c|c|c|c|c|c|}
\hline Climate & $\begin{array}{l}\text { Cities (for } \\
\text { these climatic } \\
\text { conditions) }\end{array}$ & $\begin{array}{c}\text { Initial } \\
\text { HED } \\
\left(\mathrm{KWh} / \mathrm{m}^{2}\right)\end{array}$ & $\begin{array}{l}\text { Improved } \\
\text { HED } \\
\left(\mathrm{KWh} / \mathrm{m}^{2}\right)\end{array}$ & $\begin{array}{l}\text { Initial CED } \\
\left(\mathrm{KWh} / \mathrm{m}^{2}\right)\end{array}$ & $\begin{array}{c}\text { Improved } \\
\text { CED }\end{array}$ & Retrofitting Action \\
\hline Cold & Srinagar & 296.4 & 59.1 & 17.0 & 1.0 & $\begin{array}{l}\text { Insulated walls, roof and floor with expanded } \\
\text { polystyrene + three pane windows + air tight } \\
\text { construction (low air infiltration) }\end{array}$ \\
\hline Composite & New Delhi & 76.2 & 62.0 & 141.7 & 16.0 & $\begin{array}{l}\text { Insulated walls and roof }+ \text { three pane } \\
\text { windows with shading control based on solar } \\
\text { radiation + low air infiltration }\end{array}$ \\
\hline Hot \& Dry & Jodhpur & 36.8 & 33.0 & 169.3 & 19.5 & $\begin{array}{l}\begin{array}{l}\text { Insulated } \\
\text { windows } \\
\text { wills }\end{array} \text { and roof }+ \text { single pane } \\
\text { control }\end{array}$ \\
\hline $\begin{array}{l}\text { Warm \& } \\
\text { Humid }\end{array}$ & Bombay & 1.6 & 3.0 & 117.2 & 33.1 & $\begin{array}{l}\begin{array}{l}\text { Insulated } \\
\text { windows } \\
\text { control }\end{array} \\
\text { conth }\end{array}$ \\
\hline Temperate & Bangalore & 7.0 & 6.0 & 27.0 & 4.0 & $\begin{array}{l}\text { Insulated thermal envelope with shading } \\
\text { control on windows }\end{array}$ \\
\hline
\end{tabular}

Figure 11 \& Figure 12 show the comparison between the initial and best-improved energy situation using retrofit 
solutions for buildings located at different climatic cities. The total energy demand (heating and cooling) can be reduced by far or all locations.

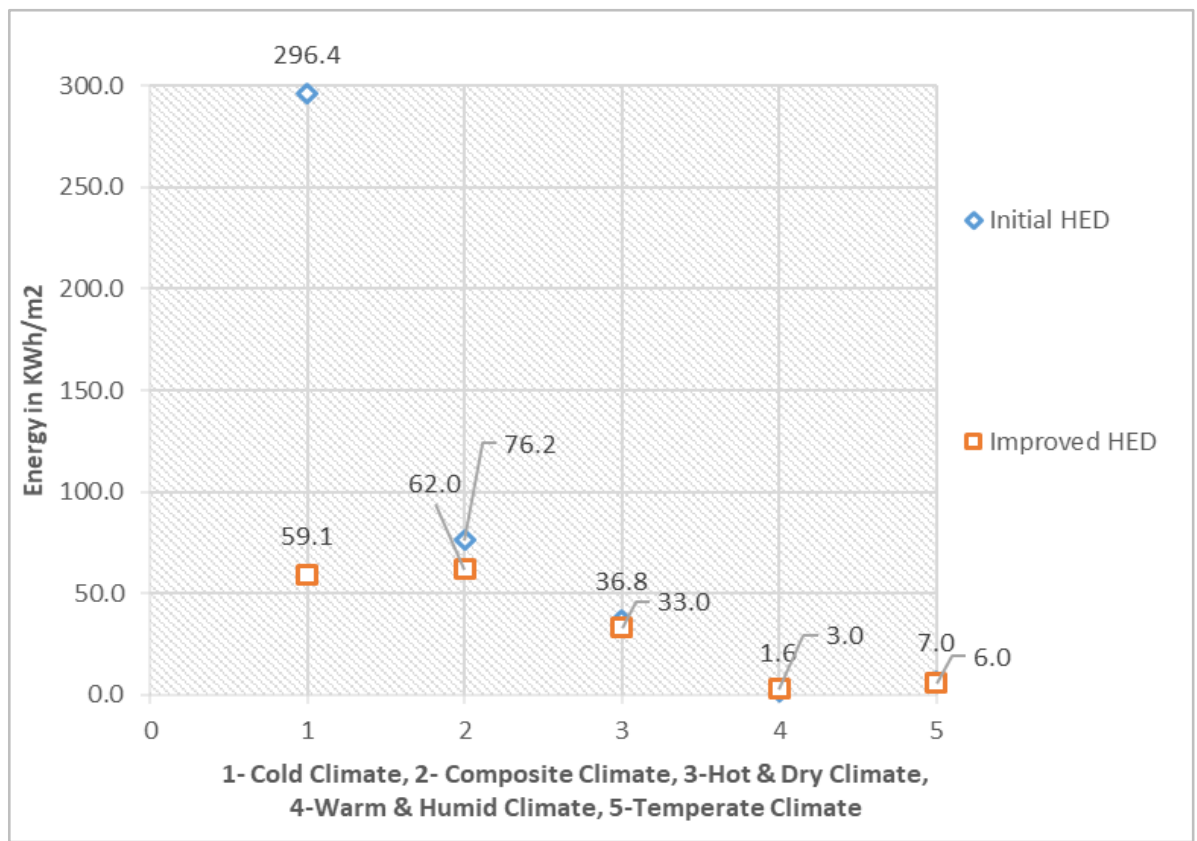

Figure 11. Initial and improved heating energy demand at five different climates of India. Here, HED- Heating Energy Demand and CED- Cooling Energy Demand

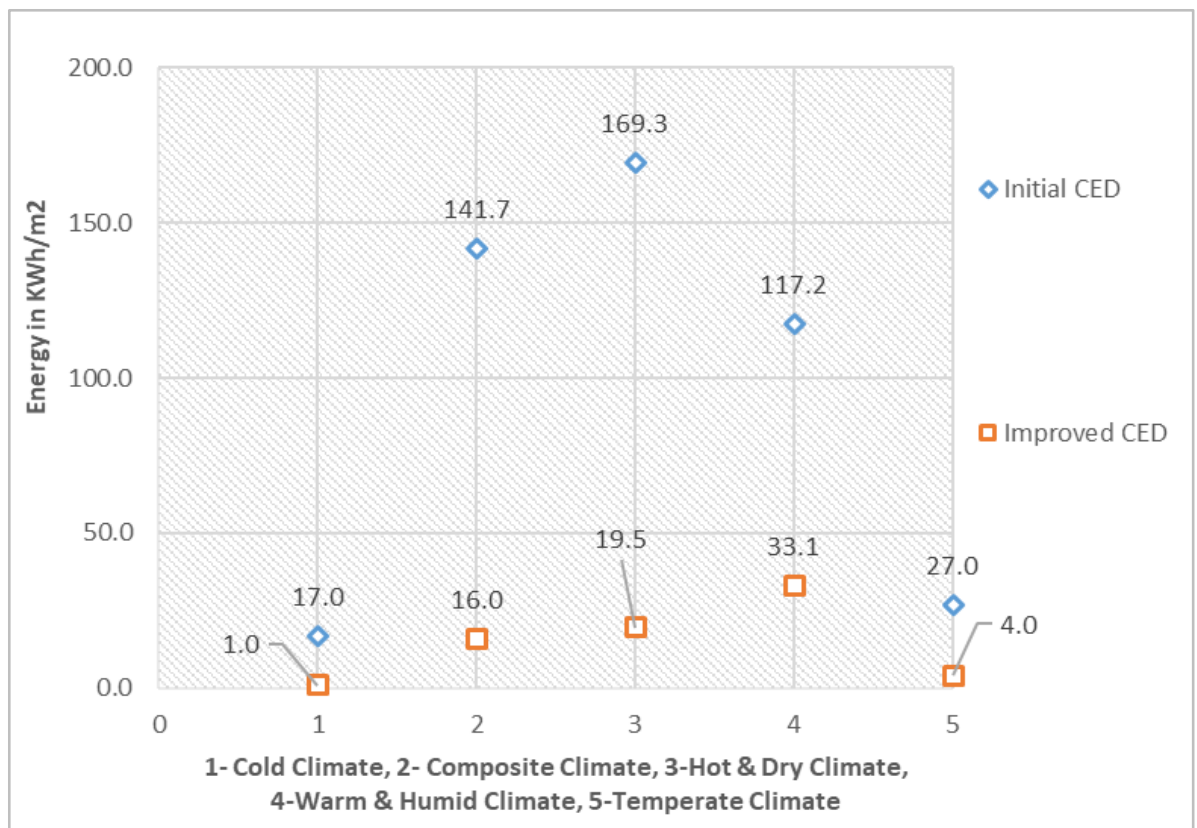

Figure 12. Initial and improved cooling energy demand at five different climates of India. Here, HED- Heating Energy Demand and CED- Cooling Energy Demand

\subsection{Results Concerning Thermal Comfort}

The fluctuation of the PMV index with respect to hours was derived for the actual and the improved building scenarios based on simulation results, which is shown in Figure 13. The thermally improved concepts are also improving the comfort conditions in the building. 


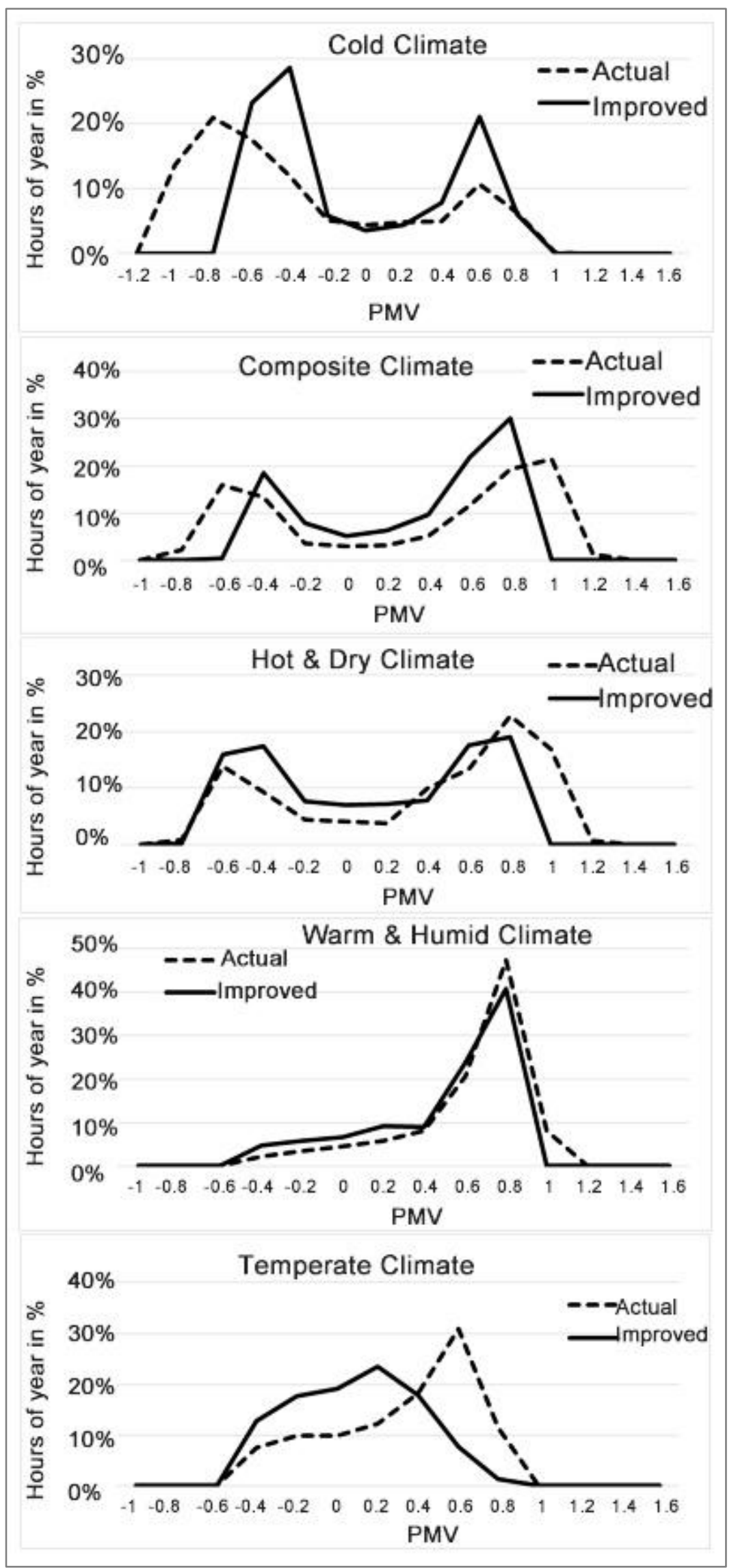

Figure 13. Change in the thermal comfort index PMV for actual (reference) and improved scenario at five climatic situations. 


\section{Conclusions}

The present work represents a step forward to the simulation results of numerous retrofitting strategies applied to a residential house, which was assumed to be located at the five climates of India. The effect of insulation, infiltration, low U-value windows were verified to quantify the impact of these parameters on heating and cooling energy demand of the building. General findings of this study were:

1. The same retrofit behaves in a different way at diverse climate conditions.

2. Air tight construction has up to $30 \%$ potential of energy savings under all the five climate conditions.

3. Replacing single pane windows with highly efficient double-pane or triple-pane windows has nearly $20 \%$ potential of energy savings for cold climate.

4. Roof insulation can save up to $15 \%$ of energy demand depending on climate.

5. Thermal envelope insulation should be considered for the locations where the heating energy demand is at $50 \%$ or more of the total energy demand of the building.

6. Retrofitting combinations are also responsible to create more thermal comfort inside the building (Figure 13).

Recommendations of retrofit solutions for individual climates based on the results of this study:

\subsection{Cold Climate}

Reduction of the heating energy demand for the buildings located in cold climate was the main driving force of retrofitting selection for the energy solution in buildings. In this work, we found that improving the thermal insulation of the building envelope with airtight construction layers and efficient windows has the biggest impact for buildings located in cold climate. With this retrofit solution, more than $80 \%$ of the total energy demand can be reduced in buildings located in cold climate.

The annual average percentage of people dissatisfied (PPD) for the actual scenario was $28 \%$, which reduced to $12 \%$ with the optimized retrofitting solution.

\subsection{Composite Climate}

For the composite climate, we chose New Delhi location where just $10 \%$ are the HDD while $90 \%$ are the CDD. Inevitably in such a climate it is more important to focus on the requirement of cooling energy demand while selecting the retrofitting solution for the building. In the analysis we found that, the total (heating and cooling) energy demand can be reduced about $65 \%$ if the roof and walls are insulated and windows have external shading control.
It was noted that in this study the shading control was defined based on radiation on glazing and was activated only in summer days. Further, by replacing single-pane windows with triple-pane windows, the total energy demand of the building was reduced by more than $82 \%$ of the initial energy demand. Also, the interesting finding in additional simulations for this climate was that the floor insulation had a massive potential of decreasing heating energy demand of the building but simultaneously it caused increased cooling energy demand. This showed that in winter days some temporary floor insulation like carpets would be a better solution than applying permanent floor insulation.

The annual average percentage of people dissatisfied was reduced from $40 \%$ to $28 \%$, with the optimized retrofitting solution.

\subsection{Hot \& Dry Climate}

Based on simulation results, it was found that for the hot \& dry climate retrofits should be oriented towards airtight construction, which means low infiltration, roof insulation, and shading control. Airtight construction, insulated roof with shading device, and the total energy demand (heating and cooling energy demand) could be reduced by more than $50 \%$. Further, insulated walls of the construction can further decrease the energy demand more than $70 \%$ compared to the initial energy demand. However, the ground surface should not be insulated. Floor insulation leads to thermal comfort in winter days but plays a major role in increasing cooling demand drastically in summer. In this situation, a temporary solution like carpet should be used to keep the floor warm in winter days.

In the initial scenario the yearly average percentage of people dissatisfied was more than $40 \%$ year-round, which reduced to less than $25 \%$ with the improved retrofitting solution.

\subsection{Warm \& Humid Climate}

For the warm \& humid climate, the heating energy demand was only $1.5 \%$ of the total cooling energy demand of the year. Therefore, we focused on reducing the cooling energy demand for a warm \& humid climate. Comparative analysis of simulation results showed low infiltration, insulated wall and shading control can reduce total energy demand (heating and cooling energy demand) by up to $70 \%$. Further insulation of walls can not only reduce the cooling demand of the building but also increase the heating energy demand by 15 times the initial heating energy demand.

In the initial scenario, the yearly average percentage of people dissatisfied was more than $30 \%$, which is reduced by $5 \%$ with improved retrofitting solution. 


\subsection{Temperate Climate}

For temperate climate, there were no heating degree days. This made it clear that only cooling energy demand needs to be taken care of while finding the retrofitting solution for energy demand. In this work, the series of retrofitting strategies were analyzed to find the best energy solution. At temperate climate, even the initial energy demand to create thermal comfort was comparably low. Through the analysis, we found that the cooling energy demand can be reduced by approximately $85 \%$ by better airtight construction which means low infiltration and shading devices. We found for temperate climate that equipping the building with insulated construction layers i.e. walls, roofs, and floors reduces the low heating demand further.

The annual average percentage of people dissatisfied was approximately $30 \%$ for initial building specification, which was reduced by approximately $10 \%$ with the improved retrofitting solution.

Future research could be on including life cost analysis and payback analysis of theses retrofitting strategies including more real time and location-based database. Also, indoor air quality could be examined for different retrofitting scenarios in order to achieve optimized thermal comfort in building.

\section{Acknowledgements}

This work is supported by the Leopold Franzens University Innsbruck, Grant Code 2017/TECH-22, Doctoral Scholarship from the youth development at the university of Innsbruck 1 tranche 2017.

\section{REFERENCES}

[1] Apeksha Shandilya, Wolfgang Streicher, "Performance and Cost Analysis of Retrofit Strategies Applied to a Sample Single Family House Located in New Delhi India Assisted by TRNSYS Energy Simulation Tool -A Case Study," International Journal of Engineering and Technical Research , vol. 6, no. 11, pp. 304-312, 2017.

[2] Bashar Basarir, Cueneyt Diri Berrin Diri, "Energy efficient retrofit methods at the building envelopes of the school buildings," energy salford.

[3] Ingy El-Darwish, Mohamed Gomaa, "Retrofitting strategy for building envelopes to achieve energy efficiency," Alexandria Engineering Journal, vol. 56, no. 4, pp. 579-589, 2017.

[4] H. Government, "Building regulations 2000: Approved Document LIA: Conservation of fuel and power in new dwellings," London.

[5] EPBD, "EC Europa," [Online]. Available: https://ec.europa.eu/energy/en/topics/energy-efficiency/ener gy-performance-of-buildings. [Accessed 17 October 2017].

[6] U. Nations, "Un.org," 2019. [Online]. Available: https://www.un.org/en/sections/about-website/terms-use/in dex.html. [Accessed November 2019].

[7] R. Gladstone, India Will Be Most Populous Country Sooner Than Thought, U.N. Says, New York: The New York Times, 2015.

[8] V. Mohan, "India on track to meet its Paris pledges despite growing emission," The Economic Times, 2018.

[9] IEO, "Today in energy," Energy Information administration, 2017.

[10] R. R. Shukla, "A report on residential buildings in India: "Energy use projections and saving potentials"," 2014.

[11] Boon E, Ahenkan A, "Assessing Climate Change Impacts on Ecosystem Services and Livelihoods in Ghana: Case Study of Communities around Sui Forest Reserve." Journal of Ecosystem \& Ecography, 2012.

[12] IPCC, "Fourth assessment report: Climate Change," 2007.

[13] UNEP, Buildings and Climate Change. Summary of decision makers. France: UNEP.

[14] Lucon O., D. Ürge-Vorsatz, A. Zain Ahmed, H. Akbari, P. Bertoldi, L.F. Cabeza, N. Eyre, A. Gadgil, L.D.D. Harvey, Y. Jiang, E., Buildings. In: Climate Change 2014: Mitigation of Climate Change. Contribution of Working Group III to the Fifth Assessment Report of the Intergovernmental Panel, Cambridge, United Kingdom and New York, NY, USA.: Cambridge University Press, 2014.

[15] Mark Dowson and Adam Poole and David Harrison and Gideon Susman, "Domestic UK retrofit challenge: Barriers, incentives and current performance leading into the green deal," Energy Policy, vol. 50, pp. 294 - 305, 2012.

[16] Sean Doran, Gabriela Zapata and Christopher Tweed, Christine Suffolk, Timothy Forman and Andrew Gemmell, "Solid wall heat losses and the," Building Research Establishment Ltd. (BRE), UK, 2014.

[17] Ahmed F. Radwan, Ahmed A. Hanafy, Mohamed Elhelw, Abd El-Hamid A. El-Sayed, "Retrofitting of existing buildings to achieve better energy-efficiency in commercial building case study: Hospital in Egypt," vol. 55, no. 4, pp. 3061-3071, 1 September 2016.

[18] Mohamed Edeisy and Carlo Cecere, "Envelope Retrofit in Hot Arid Climates," 2017.

[19] Mark Levine, Wei Feng, Jing Ke, Tianzhen Hong and Nan Zhou, "A retrofit tool for improving energy efficiency of commercial buildings," ACEEE Summer Study on Energy Efficiency in Buildings, 2012.

[20] Bano, Farheen and Sehgal, Vandana, "Evaluation of energy-efficient design strategies: Comparison of the thermal performance of energy-efficient office buildings in composite climate, India," Solar Energy, vol. 176, pp. 506-519, 102018.

[21] C. J.H., "The Indian Summer Monsoon," Graphical Reviews, vol. 57, no. 3, pp. 373-396, 1967.

[22] Senapati, Manas, "Impact of Climate Change on Indian Agriculture \& Its Mitigating Priorities Cite This Article," 
American Journal of environmental protection, vol. 1, p. 109, 112013.

[23] B. o. E. Efficiency, Energy Conservation Building Code, New Delhi: Bureau of Energy Efficiency, 2017.

[24] Attri, S D and Tyagi, Ajit, "Climate profile of India," Contribution to the Indian Network of Climate Change Assessment (NATIONAL COMMUNICATION-II), vol. 1, pp. 1-129, 012010.

[25] M. AG, "https://meteonorm.com/," Meteotest. [Online]. [Accessed 2017].

[26] I. M. Dept, The Indian Astronomical Ephemeris for the year 2000, New Delhi: New Alipore, Calcutta. Positional Astronomy Centre Controller of Publications, 1999.

[27] de Dear, Richard and Brager, Gail and D, Cooper, "Developing an Adaptive Model of Thermal Comfort and Preference - Final Report on RP-884," ASHRAE Transactions, vol. 104, 011997.

[28] S. J. A., "A Mathematical Model of Physiological Temperature Regulation in Man," NASA, 1971.

[29] G. A.P., "Rational Temperature Indices of Man's Thermal Environment and Their Use with a 2-node Model of His
Temperature Regulation," in Federal Proceedings, 1973.

[30] F. P.O., Thermal Comfort, New York: McGraw-Hill, 1972.

[31] TRNSYS, "http://www.trnsys.com/," Thermal Energy System Specialists, LLC, Madison, USA, 2018. [Online]. Available: WWW.trnsys.com.

[32] prEN137779, Writer, Ventilation for non-residential buildings: Performance requirements for ventilation and room-conditioning systems. [Performance].

[33] Standard-Nutzungsbedingungen für die Energie und Gebäudetechnik. [Performance]. SIA.

[34] "India Energy Scenario - 2047," Planning Commission-New Delhi, New Delhi, 2016.

[35] Htut AY, Shrestha S, Nitivattananon V, Kawasaki A, "Forecasting Climate Change Scenarios in the Bago River Basin, Myanmar," Journal of Earth Science \& Climatic Change, October 2014.

[36] Ingy El-Darwish and Mohamed Gomaa, "Retrofitting strategy for building envelopes to achieve energy efficiency," Alexandria Engineering Journal, vol. 56, no. 4, pp. 579-589, 2017. 